\title{
Molecular Survey on Leishmania Infantum Infection in Red Foxes (Vulpes Vulpes) From Romania
}

\author{
Angela Monica IONICĂ, Georgiana DEAK, Zsuzsa KALMÁR, Călin Mircea GHERMAN, Andrei Daniel \\ MIHALCA, Mirabela Oana DUMITRACHE*
}

Department of Parasitology and Parasitic Diseases, Faculty of Veterinary Medicine, University of Agricultural Sciences and Veterinary Medicine Cluj-Napoca, 3-5 Calea Mănăștur, 400372, Cluj-Napoca, Romania

* corresponding author: mirabela.dumitrache@usamvcluj.ro

Bulletin UASVM Veterinary Medicine 74(2)/2017

Print ISSN 1843-5270; Electronic ISSN 1843-5378

doi:10.15835/buasvmen-vm:0054

\begin{abstract}
Leishmania spp. (Kinetoplastida, Trypanosomatidae) are parasitic protozoans transmitted by sand flies to animals and humans. In Europe, the predominant species is Leishmania infantum, the agent of canine leishmaniasis (CanL) and of visceral (VL) and cutaneous (CL) forms in humans. Despite being regarded as a non-endemic country, recent data from Romania have shown the occurrence of autochthonous cases of human and canine infections. The aim of this study was to investigate the occurrence of L.infantum in red foxes (Vulpes vulpes) from Romania. Between December 2016 and April 2017, 514 foxes originating from ten counties of Romania were evaluated and individual conjunctival swab samples were tested for the presence of $L$. infantum DNA by means of real-time PCR. All samples were negative. However, considering the new national epidemiological context, the importance of the red fox as sentinel and its potential role in the epidemiology of this disease in Romania should not be disregarded in the future.
\end{abstract}

Keywords: Leishmania, CanL, Vulpes vulpes, Romania

\section{INTRODUCTION}

Leishmania spp. (Kinetoplastida, Trypanosomatidae) are parasitic protozoans transmitted by female sand flies to animals and humans (Schönian et al., 2010). In Europe, three species have been reported so far: L. infantum, which is the predominant species and the agent of canine leishmaniasis (CanL) and of visceral (VL) and cutaneous (CL) forms in humans (Otranto and Dantas-Torres, 2013); anthroponotic L. tropica and $L$. donovani, which have a focal distribution, occasionally causing VL and CL in Greece and Cyprus (Mazeris et al., 2010).

CanL is regarded as an endemic disease along the Mediterranean coast, from Portugal to Turkey (Maia and Cardoso, 2015). However, an expanding trend has recently been noted, with cases being reported in northwestern Italy, as well as in other Central European countries (Maroli et al., 2008; Schönian et al., 2010), due to the spreading of sand fly populations, the extension of their breeding seasons and the shortening of their larval development, as a consequence of climate change (Killick-Kendrick, 1996; Desjeux, 2001). Furthermore, the traveling and temporary or permanent relocation of dogs together with their owners may also facilitate the spreading of the disease throughout Europe (Maia and Cardoso, 2015).

In Romania, between 1969 and 2013, all cases of canine or human infection were imported (Dumitrache et al., 2016). Recently, after more than 80 years of absence of clinical CanL, an autochthonous case was described in 2014, in a dog from Vâlcea County (Mircean et al., 2014) and a focal serological prevalence of $8.7 \%$ was subsequently established in apparently healthy dogs originating from the same area (Dumitrache 
et al., 2016). Furthermore, L. infantum infection was recently confirmed by PCR screening also in a golden jackal originating from Romania (Mitková et al., 2017).

Romania holds an important wildlife-domestic animal interface. Among wild carnivore species, the red fox (Vulpes vulpes) is the most widely distributed at a national level, with an estimated population of more than 63.000 specimens in 2013, according to the Romanian Ministry of Environment. As for many wildlife species, red foxes may also play a role in the epidemiology of CanL (Millán et al., 2014) and no recent studies regarding the national distribution of the infection nor its sand fly vectors are currently available from Romania, the aim of the present study was to investigate the molecular occurrence of $L$. infantum in red foxes from Romania.

\section{MATERIALS AND METHODS}

Between December 2016 and April 2017, a total of 514 red foxes originating from ten counties of Romania were evaluated. All the animals were legally hunted and collected by the National Sanitary Veterinary Authority during the rabies monitoring program. From each examined fox, conjunctival secretions were collected using a sterile swab. All swabs were labeled and stored at $-20^{\circ} \mathrm{C}$ until further processing. Genomic DNA was extracted individually from each swab, following suspension in $300 \mu \mathrm{l} 1 \mathrm{x}$ PBS, using a commercial kit (Isolate II Genomic DNA Kit, BIOLINE, UK) according to the manufacturer's instructions. The DNA samples were processed by means of real-time PCR amplification of the kinetoplast minicircle DNA of L. infantum, using the LEISH-1/ LEISH-2 primer pair and TaqMan-MGB probe, as previously described (Francino et al., 2006).

\section{RESULTS AND DISCUSSION}

All of the 514 examined samples were negative for $L$. infantum DNA. With concern to leishmaniasis, Romania is generally regarded as a non-endemic country, with a low risk (Ready, 2010). However, in the past century, between 1912 and 1955, 27 autochthonous human cases have been documented from southern Romania. In the area were human cases were diagnosed; several studies investigating dog population were performed. Thus, in 1967, in a study performed in Dolj County, the prevalence of infection was of
$1.2 \%$, while in another survey performed in 1968 in Caraș-Severin County, it was 2.2\% (Mircean etal., 2014). All dogs were apparently healthy. Between 1969 and 2013, no other autochthonous cases were reported. More recent investigations found a serological prevalence of $2.9 \%$ in apparently healthy dog population originating from Bucharest area (Hamel et al., 2012). In Râmnicu Vâlcea (city in Vâlcea County), where a clinical case of CanL was described (Mircean et al., 2014), a total of 12 apparently healthy dogs (representing $15 \%$ of all tested animals) were positive, either by means of serological testing $(n=7,8.7 \%)$ or by real-time PCR $(n=8,10 \%)$, raising public health concerns (Dumitrache et al., 2016).

Generally, the domestic dog is regarded as the main reservoir of $L$. infantum, due to several factors, including the susceptibility to infection, the great ability to transmit the parasite to the phlebotomine vectors and last but not least, its proximity to humans (Ready, 2010; DantasTorres et al., 2014). However, cases of Leishmania infection were confirmed also in several species of wild carnivores in Europe (as reviewed by Millán et al., 2014), including canids (golden jackal - Canis aureus, grey wolf - C. lupus, red fox - Vulpes vulpes), felids (Iberian lynx - Lynx pardinus, European wild cat - Felissilvestris), mustelids (polecat - Mustelaputorius, European mink - M.lutreola, weasels - Mustela spp., stone marten - Martesfoina, pine marten - M. martes, European bdger - Melesmeles), viverids (common genet - Genettagenetta) and herpestids (Egyptian mongoose - Herpestes ichneumon). Furthermore, the grey wolf and the red fox may also display clinical signs of the disease (Millán et al., 2014).

Recent molecular surveys of foxes originating from endemic countries have shown a prevalence of Leishmania infection of 9\% in southern France (Davoustet al., 2014), 1.3\% in northern, central and southern Portugal (Cardoso et al., 2015), 59.5\% in West Fthiotida prefecture in Greece (Karayiannis et al., 2015) and $20.8 \%$ in southern Italy (Piantedosi et al., 2016). With regards to the targeted samples, the highest prevalence was recorded in splenic tissue (Davoust et al., 2014; Karayiannis et al., 2015; Piantedosi et al., 2016), while most blood samples (Davoust et al., 2014; Karayiannis et al., 2015) and all skin samples (Davoust et al., 2014) were negative. This raises a question regarding the actual ability of the fox to efficiently transmit 
the parasite to the phlebotomine vectors. In crabeating foxes (Cerdocyonthous) it was shown that animals harboring a sub-clinical infection were non-infectious to the vector (Piantedosi et al., 2016). However, transmission from red foxes to sand flies has not been documented so far. Clinical signs suggestive for leishmaniasis were observed only in Greece, in 20 out of 28 positive foxes. However, as the recorded clinical signs were not strictly specific for the disease, they could also be attributed to other conditions, such as nutritional deficiencies and the occurrence of other parasitic diseases (Karayiannis et al., 2015).Similarly, in southern Italy, a frequent finding compatible with leishmaniasis in positive foxes was weight loss, which could more likely be attributed to the concurrent presence of lung and intestinal worms (Piantedosi et al., 2016).

The prevalence of infection in foxes was lower compared to dogs living in the same study areas, indicating a lower exposure risk, but highlighting their importance as sentinel hosts (Davoust et al., 2014; Cardoso et al., 2015; Karayiannis et al., 2015; Piantedosi et al., 2016).

Among wild carnivores, red foxes are among the most widely distributed species worldwide and the most adapted to synanthropic ecosystems (Duscher et al., 2014). Therefore, despite our negative results, in the context of geographical spreading of CanL, the importance of the red fox as sentinel and its potential role in the epidemiology of this disease in Romania should not be disregarded in the future and further research should be carried out.

Acknowledgements: The study was supported by the CNCS-UEFISCDI Grant Agency Romania; grant number TE 299/2015.We would like to express our gratitude to the hunters and the representatives of The Sanitary Veterinary Authority for providing the samples.

\section{REFERENCES}

1. Cardoso L, Gilad M, Cortes HC, Nachum-Biala Y, Lopes AP, Vila-Viçosa MJ, Simões, M, Rodrigues PA, Baneth G (2015). First report of Anaplasma platys infection in red foxes (Vulpes vulpes) and molecular detection of Ehrlichiacanis and Leishmania infantum in foxes from Portugal. Parasit. Vectors, 8:144.

2. Davoust B, Mary C, Marié JL (2014). Detection of Leishmania in red foxes (Vulpes vulpes) from southeastern France using real-time quantitative PCR. J. Wildl. Dis., 50:130132.

3. Dantas-Trorres F, Baneth G, Miró G, Cardoso L, Oliva G, Solano-Gallego L, Bourdeau P, Otranto D (2014). Further thoughts on "Asymptomatic dogs are highly competent to transmit Leishmania (Leishmania) infantum chagasi to the natural vector". Vet. Parasitol., 204:443-444.

4. Desjeux P (2001). The increase in risk factors for leishmaniasis worldwide. Trans. R. Soc. Trop. Med. Hyg., 95:239-243.

5. Dumitrache MO, Nachum-Biala Y, Gilad M, Mircean V, Cazan CD, Mihalca AD, Baneth G (2016). The quest for canine leishmaniasis in Romania: the presence of an autochthonous focus with subclinical infections in an area where disease occurred. Parasit. Vectors., 9, 297.

6. Duscher GG, Fuehrer HP, KübberHeiss A (2014). Fox on the run-molecular surveillance of fox blood and tissue for the occurrence of tick-borne pathogens in Austria. Parasit. Vectors., 7, 521.

7. Francino O, Altet L, Sanchez-Robert E, Rodriguez A, Solano-Gallego L, Alberola J, Ferrer L, Sánchez A, Roura X (2006) Advantages of real-time PCR assay for diagnosis and monitoring of canine leishmaniosis. Vet. Parasitol., 137:214-221.

8. Hamel D, Silaghi C, Lescai D, Pfister K (2012). Epidemiological aspects on vector-borne infections in stray and pet dogs from Romania and Hungary with focus on Babesia spp. Parasitol. Res., 110:1537-1545.

9. Karayiannis S, Ntais P, Messaritakis I, Tsirigotakis N, Dokianakis E, Antoniou M (2015). Detection of Leishmania infantum in red foxes (Vulpes vulpes) in Central Greece. Parasitology, 142:1574-1578.

10. Killick-Kendrick R (1996). Leishmaniasis - an English disease of the future? Trop. Med. Int. Health., 4,5.

11. Maia C, Cardoso L (2015). Spread of Leishmania infantum in Europe with dog travelling. Vet. Parasitol., 213:2-11.

12. Maroli M, Rossi L, Baldelli R, Capelli G, Ferroglio E, Genchi C, Gramiccia M, Mortarino M, Pietrobelli M, Gradoni L (2008). The northward spread of leishmaniasis in Italy: evidence from retrospective and ongoing studies on the canine reservoir and phlebotomine vectors. Trop. Med. Int. Health., 13:256-264.

13. Mazeris A, Soteriadou K, Dedet JP, Haralambous C, Tsatsaris A, Moschandreas J, Messaritakis I, Christodoulou V, Papadopoulos B, Ivovic V, Pratlong F, Loucaides F, Antoniou M (2010). Leishmaniases and the Cyprus paradox. Am. J. Trop. Med. Hyg., 82:441-448.

14. Millán J, Ferroglio E, Solano-Gallego L (2014). Role of wildlife in the epidemiology of Leishmania infantum infection in Europe. Parasitol. Res., 113:2005-2014.

15. Mircean V, Dumitrache MO, Mircean M, Bolfa P, Györke A, Mihalca AD (2014). Autochthonous canine leishmaniasis in Romania: neglected or (re) emerging?. Parasit. Vectors, 7:135

16. Mitková B, Hrazdilová K, D’Amico G, Duscher GG, Suchentrunk F, Forejtek P, Gherman CM, Matei IA, Ionică AM, Daskalaki AA, Mihalca AD, Votýpka J, Hulva P, Modrý 
D (2017). Eurasian golden jackal as host of canine vectorborne protists. Parasit. Vectors, 10:183.

17. Otranto D, Dantas-Torres F (2013). The prevention of canine leishmaniasis and its impact on public health. Trends Parasitol., 29:339-345.

18. Piantedosi D, Veneziano V, Di Muccio T, Manzillo VF, Fiorentino E, Scalone A, Neola B, Di Prisco F, D’Alessio N, Gradoni L, Oliva G, Gramiccia M (2016).Epidemiological survey on Leishmania infection in red foxes (Vulpes vulpes) and hunting dogs sharing the same rural area in Southern Italy. Acta Parasitol., 61:769-775.

19. Ready PD (2010). Leishmaniasis emergence in Europe. Euro Surveill., 15:19505.

20. Schönian G, Mauricio I, Cupolillo E. (2010). Is it time to revise the nomenclature of Leishmania? Trends Parasitol., 26:449-466. 